\title{
AlpArray in Hungary: temporary and permanent seismological networks in the transition zone between the Eastern Alps and the Pannonian basin
}

\author{
Zoltán Gráczer $^{1}$ (D) - Gyöngyvér Szanyi ${ }^{1} \cdot$ István Bondár $^{1} \cdot$ \\ Csenge Czanik $^{1}$ - Tibor Czifra ${ }^{1} \cdot$ Erzsébet Györi $^{1} \cdot$ György Hetényi $^{1,2}$. \\ István Kovács $^{1} \cdot$ Irene Molinari $^{3} \cdot$ Bálint Süle $^{1} \cdot$ Eszter Szúcs $^{1}$ • \\ Viktor Wesztergom ${ }^{1} \cdot$ Zoltán Wéber $^{1} \cdot$ AlpArray Working Group
}

Received: 29 September 2017/ Accepted: 14 February 2018/Published online: 20 March 2018

(C) The Author(s) 2018

\begin{abstract}
In the last few decades dense large-scale seismic networks showed their importance in studying the structure of the lithosphere and the upper mantle. The better understanding of the Apennines-Alps-Carpathian-Dinarides system is the main target of the AlpArray European international initiative in which more than 50 institutes are involved. The core of AlpArray is the AlpArray Seismic Network (AASN). With its $\sim 600$ broadband seismic stations ( $\sim 280$ of which are temporary) the AASN is, so far, the largest passive seismic experiment in Europe. The MTA CSFK Geodetic and Geophysical Institute, as a Core Member of the AlpArray project, contributes to the AlpArray Seismic Network with its entire permanent network as well as with 11 temporary broadband seismic stations deployed in Western Hungary. Three additional station equipment were provided by the Swiss-AlpArray SINERGIA program. The average station distance together with the permanent stations is around $40 \mathrm{~km}$ in the area of interest. The temporary network has been installed between December 2015 and July 2016 and the planned operation period is 3 years. In this paper we describe the characteristics of the 29 permanent and temporary stations, introducing not only the equipment, but the location, housing and geological setting, as well. We present median power spectral density curves in order to characterise the noise conditions at each station.
\end{abstract}

Keywords AlpArray · Temporary seismic network · Hungarian National Seismological Network · Pannonian basin · Seismic noise

Zoltán Gráczer

graczer.zoltan@csfk.mta.hu

1 Geodetic and Geophysical Institute, Research Centre for Astronomy and Earth Sciences, Hungarian Academy of Sciences, Csatkai E. u. 6-8., Sopron 9400, Hungary

2 Institute of Earth Sciences, University of Lausanne, UNIL-Mouline Géopolis, 1015 Lausanne, Switzerland

3 Institute of Geophysics, Department of Earth Sciences, ETH Zürich, 8092 Zurich, Switzerland 


\section{Introduction}

AlpArray (http://www.alparray.ethz.ch) is a European collaborative project with the involvement of more than 50 institutes (universities, observatories, research institutes etc.) from 18 countries. It aims at studying the orogenic process and the structure of the crust and upper mantle in the greater Alpine region by using seismological and other geophysical methods. Within AlpArray, the AlpArray Seismic Network (AlpArray Seismic Network 2015) is collecting high quality seismic data which are the fundamental prerequisite to address the open questions on the Alpine orogeny (for details see Hetényi et al. 2018, submitted). The AlpArray Seismic Network (AASN) is, at present day, the largest large-scale passive seismic experiment in Europe. It officially began its operation on 1st of January 2016 and will run for at least 3 years. AlpArray in Hungary aims for a deeper understanding of the tectonics and geodynamics in the transition zone between the Eastern Alps and the Pannonian basin.

The Hungarian Academy of Sciences, Research Centre for Astronomy and Earth Sciences, Geodetic and Geophysical Institute (MTA CSFK GGI) contributes to the AlpArray Seismic Network with its entire permanent network as well as with 11 temporary broadband seismic stations deployed in Western Hungary (Fig. 1). Three additional station equipment were provided by the Swiss-AlpArray SINERGIA program for the stations A271A, A272A and A273A, which are co-managed with ETH Zurich. The average interstation distance together with the permanent stations is around $40 \mathrm{~km}$ in the area of interest. The temporary network has been installed between December 2015 and July 2016. The planned operation period is 3 years.

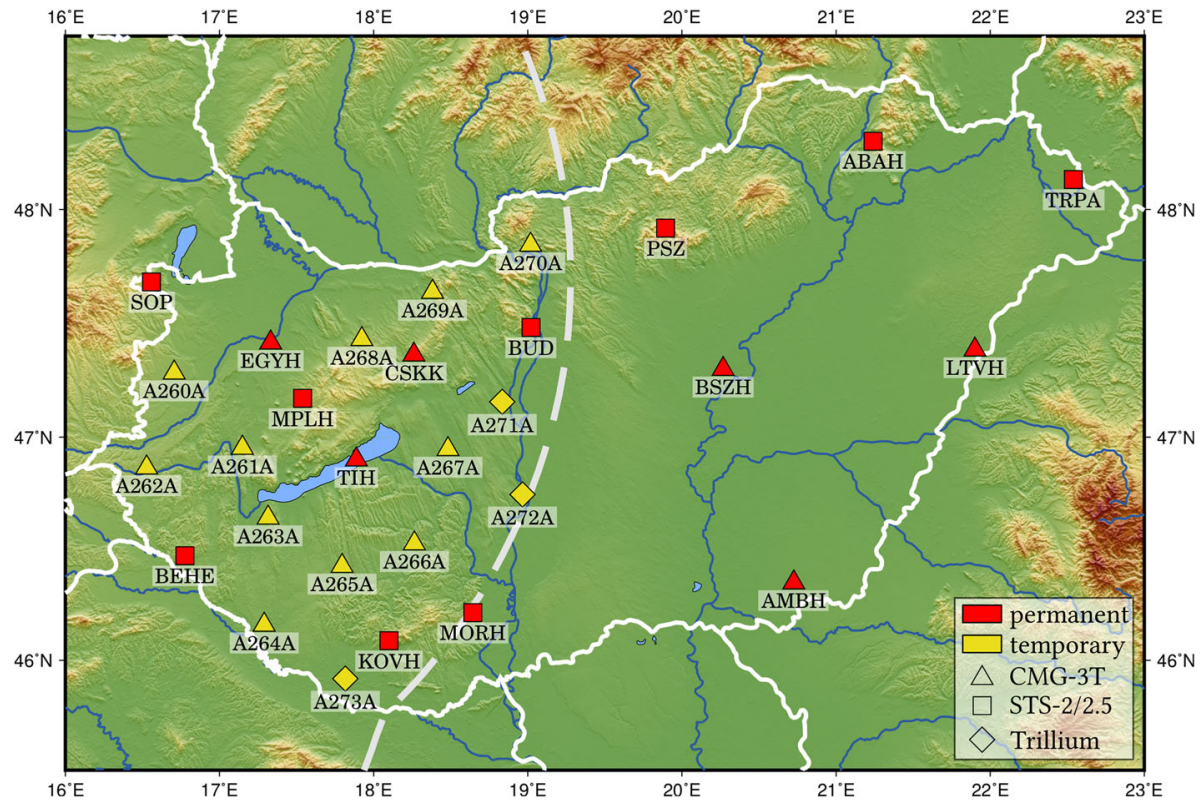

Fig. 1 Seismological stations in Hungary operated by the MTA CSFK GGI Kövesligethy Radó Seismological Observatory. Red symbols: permanent, yellow symbols: temporary (AlpArray) stations of the Hungarian National Seismological Network. Triangle: Guralp CMG-3T 120 s seismometers, square: Streckeisen STS-2 or STS-2.5 seismometers, diamond: Nanometrics Trillium Compact 120 s sensors. Dashed line: $250 \mathrm{~km}$ distance contour around the Alps. (Color figure online) 
In this paper we describe the research goals and objectives of the Hungarian participation in the AlpArray project. We present the characteristics of the Hungarian National Seismological Network (which currently consists of the permanent stations and the AlpArray temporary stations), describe the seismic network requirements for the AASN and show the site selection criteria and process. In addition, we give a detailed description of the permanent and temporary stations introducing their equipment, locations, housings and geological settings. Finally, we describe the performance of the broadband stations, summarising the most important noise characteristics.

\section{Research aims and objectives of the Hungarian AlpArray project}

The Carpathian-Pannonian region (CPR) is an exceptional natural laboratory to understand the architecture and dynamics of the lithosphere. The reasons are mainly found in the complex geological processes which lead, in the last $30 \mathrm{Ma}$, to the formation of the Pannonian basin and surrounding mountain belts (i.e. Alps, Dinarides and Carpathians). The main tectonic units are the Alcapa and Tisza-Dacia micro terranes which compose the basement of the region. The oceanic realms separating the main tectonic units (i.e. Penninic, Magura, Vardar) were all closed by the convergence between Adria and the stable European Platform mainly before the Paleogene (Csontos and Vörös 2004; Schmid et al. 2008). Following the closure of these oceanic domains the Alcapa and Tisza-Dacia units gradually occupied the Carpathian Embayment from the late Oligocene until the late Miocene (11 Ma; Kázmér and Kovács 1985; Fodor et al. 1999). The extrusion of these blocks overlapped with the intensive extension of the lithosphere in the central part of the CPR of which exact driving mechanism is still disputed (Huismans et al. 2001; Horváth et al. 2006; Kovács et al. 2012; Harangi et al. 2015; Balázs et al. 2016). Alcapa and TiszaDacia eventually collided with the stable European platform in the late Miocene. This resulted in the disappearance of the Carpathian Embayment marking the onset of transition into the inversional stage of the CPR which started $\sim 5 \mathrm{Ma}$ ago and still shapes the area. The main phase of the extension in the Miocene was accompanied by large scale calcalkaline volcanism in the vicinity of major tectonic zones (e.g. Mid-Hungarian Zone; Eastern Carpathian; Szabó et al. 1992; Harangi et al. 2007; Kovács and Szabó 2008); while alkaline basaltic volcanism occurred in the Plio-Pleistocene during the tectonic inversion stage (Embey-Isztin et al. 1993; Harangi et al. 2015) and produced sporadic volcanic fields in the CPR.

The AlpArray network in Hungary covers the transition from the Eastern Alps to the Pannonian Basin: a geologically particularly interesting area to understand more accurately the extrusion, extension of the main tectonic units and the effects of the subsequent tectonic inversion. With the new AASN data we will be able to outline with more detail the structure of the lithospheric units exploiting the horizontal and vertical variations in the velocity of seismic waves, anisotropy of seismic wave propagation and focal mechanism of earthquakes occurring in the area (e.g. body and surface wave tomography, receiver functions, SKS splitting etc.). The major open or disputed scientific questions which are planned to be addressed by the project are:

1. Tracing and identifying more accurately the remnants of subducted slabs beneath the CPR. Previous studies depicted a negative velocity anomaly extending towards the Alcapa unit from below the Eastern Alps at a depth of $\sim 300 \mathrm{~km}$ (Ren et al. 2012; 
Qorbani et al. 2015). The subduction 'graveyard' beneath the basin could also be imaged more accurately (Hetényi et al. 2009).

2. Understanding whether the extrusion of the major tectonic units happened at the scale of the upper crust or in the entire lithosphere (e.g. Qorbani et al. 2016). Focusing on the distribution of major vertical seismic impedance contrasts in the lithosphere could facilitate answering this question and extends earlier studies with limited coverage (e.g. Hetényi and Bus 2007; Hetényi et al. 2015).

3. It is also debated whether the major tectonic boundaries (e.g. Mid-Hungarian Zone, Rába line etc.) are only present in the crust or could be traced down all the way to the asthenosphere, cross-cutting the entire continental lithospheric mantle (c.f. Tari et al. 1999; Horváth et al. 2015; Kovács et al. 2007, 2012). This challenging topic could be resolved if horizontal heterogeneities are mapped in the lithosphere as tectonic units are likely expected to show coherent images if separated by deep fault zones (i.e. the tectonic lines on the surface are only the surface manifestation of deep faults separating entire lithospheric blocks with more or less homogeneous seismic properties). If the pattern of horizontal heterogeneities is independent of the major tectonic faults, this may imply that the crust and the lithospheric mantle are decoupled or highly heterogeneous.

4. Foliation and lineation developed in upper mantle rocks (produced by olivine the most voluminous constituent of the upper mantle) could indicate the direction of minimum stress (extensional half space). Seismic anisotropy (SKS splitting, and those obtained from ambient noise tomography at long periods) originating mainly from the lithospheric mantle and the asthenosphere can be used as a proxy for outlining the prevailing stress field under the area (Silver 1996; Vauchez et al. 2012). The direction of seismic anisotropy could be confused by frozen-in, inherited anisotropies from previous tectonic episodes. Namely, present seismic anisotropies could reflect mainly the present stress field (tectonic inversion), but directions could also bear some imprints of the prior extensional episode or local effects.

5. Studying the focal mechanisms of earthquakes can contribute to reveal whether the crust, lithospheric mantle and asthenosphere deform uniformly or heterogeneously both in horizontal and vertical sense? The focal mechanism of earthquakes occurring in Hungary could outline the present day stress field in the upper and middle crust where hypocenters are usually located (Wéber and Süle 2014; Wéber 2016a, b). These directions can be compared to those of seismic anisotropy from the crust or the underlying upper mantle. By assessing the style and rate of crustal deformation using GPS and earthquake data (e.g. Bus et al. 2009) and computing the seismic/geodetic strain rate ratio the deformation mechanism, rheology and tectonic style of the CPR can be studied. Consequently the kinematics of lithosphere deformation at the transition between the Eastern Alps and the Pannonian basin could be constrained more accurately.

\section{The Hungarian National Seismological Network}

The history of the Hungarian National Seismological Network (HNSN) dates back to 1902, when the first Omori-Bosch seismographs were installed in Budapest and Ógyalla (now Hurbanovo, Slovakia) (Varga 2016). The network was gradually extended up to 10 stations until 1914, however it could not avoid the devastating effect of both World Wars. Later the 
predecessors of the MTA CSFK GGI Kövesligethy Radó Seismological Observatory (KRSZO) installed and dismantled several stations during the twentieth century, but only a few stations were operating simultaneously. The number of the HNSN stations exceeded ten for the first time only in 2013. The digital registration started in 1992 in Hungary using a STS-2 seismometer at Piszkéstetö in cooperation with the German GeoForschungsZentrum. The first digital permanent station operated exclusively by the KRSZO (at that time known as MTA GGKI Seismological Observatory) was installed in Sopron in 2004.

In September 2017, the HNSN (doi:10.14470/UH028726) consists of 29 online broadband stations, 15 of them are permanent stations supplemented by 14 temporary stations deployed in the framework of the AlpArray project (Fig. 1). All the stations are operated by the KRSZO. Three stations from the 14 temporary stations are co-operated with ETH Zurich as their equipment were funded by the Swiss-AlpArray SINERGIA program.

Although the permanent part of the network spans the entire territory of Hungary, the geometry is driven by the topography. As a significant part of the country is covered by sediments and the basin depth exceeds even $7 \mathrm{~km}$ in some places, most of the stations are concentrated in hilly/mountain regions to avoid high noise levels that usually characterise sedimentary basins.

The main purpose of the network is the continuous monitoring of the seismicity of Hungary and to provide high quality data for the seismological and geodynamic scientific research. However, in order to meet social demands, in case of a felt earthquake the protocol followed by the KRSZO include the notification to official bodies, such as the National Directorate General for Disaster Management and the official Hungarian news agency (MTI). Information about the latest events are posted on the homepage of the Observatory (http://www.seismology.hu), Facebook page (http://www.facebook.com/ krszo) and Twitter account (http://www.twitter.com/szeizmologia). In addition, focal parameters and phase readings of the detected local events and macroseismic data of the felt Hungarian earthquakes are published yearly in the Hungarian National Seismological Bulletin.

All data are acquired in real-time by the HNSN data centre located in the building of the KRSZO in Budapest. The permanent part of the HNSN follows an open data policy: seismic waveform data are available in real time without any restrictions from the European Integrated Data Archive (EIDA).

\section{The AlpArray network in Hungary}

The scientific objectives set by the AlpArray project can only be achieved if the temporary and permanent stations conform to the quality requirements described in the AlpArray Technical Strategy document (Brisbourne et al. 2013). These standards include the site selection process; station equipment and settings; deployment procedure, data communication, formats and access; and the noise characteristics.

The naming of the temporary stations was strictly regulated. All the AASN temporary stations have the FDSN network code Z3. The station codes have five characters. The first one is a compulsory A. The middle characters form a three digit number (the range between 260 and 279 has been assigned to Hungary). The last character initially is an A, 
but it must be replaced by $\mathrm{B}, \mathrm{C}, \ldots$ if the station location is changed by a distance more than $20 \mathrm{~m}$.

The scouting work for the Hungarian AASN temporary stations began in June 2015. There were 14 temporary station locations planned for the western part of Hungary by the AlpArray project. To form a uniformly distributed network, stations had to be deployed at a site with less than $6 \mathrm{~km}$ distance from the preliminary location points, preferably within $3 \mathrm{~km}$ distance.

All the Hungarian station equipment and settings comply to the technical regulations. Three component broadband sensors with flat velocity-response in the frequency domain from $20 \mathrm{~Hz}$ to at least $0.03 \mathrm{~Hz}(30 \mathrm{~s})$, preferably down to $0.008 \mathrm{~Hz}(120 \mathrm{~s})$ and digitisers with $>130 \mathrm{~dB}$ dynamic range between $0.1 \mathrm{~Hz}$ and $10 \mathrm{~Hz}$ are required, together with continuous GPS timing and 100 sps or higher sampling rate. Data have to be provided in miniSEED format to EIDA and the state of health of the network should be continuously monitored in order to provide reliable data availability and quality for the AlpArray project.

According to the AASN requirements the mean or median PSD noise levels for rock or competent soil sites must be $20 \mathrm{~dB}$ lower than the New High Noise Model (NHNM, Peterson 1993) on all the three components for the 1-10 Hz frequency range. For periods between 20 and $100 \mathrm{~s}$ the horizontal and vertical noise must be lower than the NHNM level by 10 and $20 \mathrm{~dB}$, respectively. In the case of soft soil or basin sites the noise levels must be below the NHNM for all components for the above frequency ranges.

When selecting new station locations several conflicting aspects have to be considered. We searched for locations characterized by low amplitude cultural noise with main power grid and continuous internet connection (wired or mobile). In addition, our optimal site had to have high level of security to reduce the risk of damages and accessibility in all seasons. Based on these criteria we preferred unused cellars, independent vaults, rarely used cottages and funeral homes or chapels at cemeteries. Before each station installation we performed several noise level measurements in the target area in order to find the best possible site. Selection of the final location was always based on the comparison of the power spectral density plots computed at each candidate site by the method of McNamara and Buland (2004). Although it was only recommended but not prescribed, we have realized real-time data transmission at all stations.

By the beginning of March 2016 all stations but A270A were deployed. This last station was installed in July 2016. Considering the final location of the 14 stations (Fig. 1), eight stations have a distance less than $3 \mathrm{~km}$ from the preliminary location, while the other stations' distance is between 3 and $5.8 \mathrm{~km}$. The average inter-station distance for the Hungarian part of the AASN area is around $38 \mathrm{~km}$.

\section{Equipment and station design}

The HNSN consists of broadband online stations (for locations of the stations see Fig. 1). Two types of equipment are used: (1) Guralp CMG-3T 120 s seismometers with Guralp DM24S3EAM (or CMG-DAS) data acquisition units and (2) Streckeisen STS-2 or STS-2.5 seismometers with EarthData PS6 24-bit digitisers or Guralp DM24S3EAM data acquisition units. The temporary AlpArray stations are exclusively equipped with Guralp CMG3T $120 \mathrm{~s}$ sensors and Guralp DM24S3EAM digitisers. The three station equipment 
provided by ETH Zurich use Nanometrics Trillium Compact 120 s sensors and Nanometrics Taurus 3-channel 24-bit digitisers.

Stations are usually placed in stand-alone cellars, in rarely used buildings or inside vaults. Several forms of ground-sensor coupling are used. In case of the permanent stations more than half of them are installed on a concrete plinth. This is usually a concrete cube with a side length varying between $0.5 \mathrm{~m}$ and $1 \mathrm{~m}$. Deploying the sensor on concrete or tiled floor is also common. Occasionally the equipment is placed on a granite slab or directly on rock. The granite slab is usually $33 \times 33 \mathrm{~cm}$ wide and $2 \mathrm{~cm}$ thick. As the AlpArray stations are temporary, a concrete plinth was made only at two of them. In most cases the sensors are installed on the concrete or tiled floor and some are placed on granite slabs. A typical station configuration can be seen in Fig. 2.

For sensor orientation magnetic north was measured with a compass without correction for magnetic declination. In every HNSN station thermal insulation of the sensor is ensured
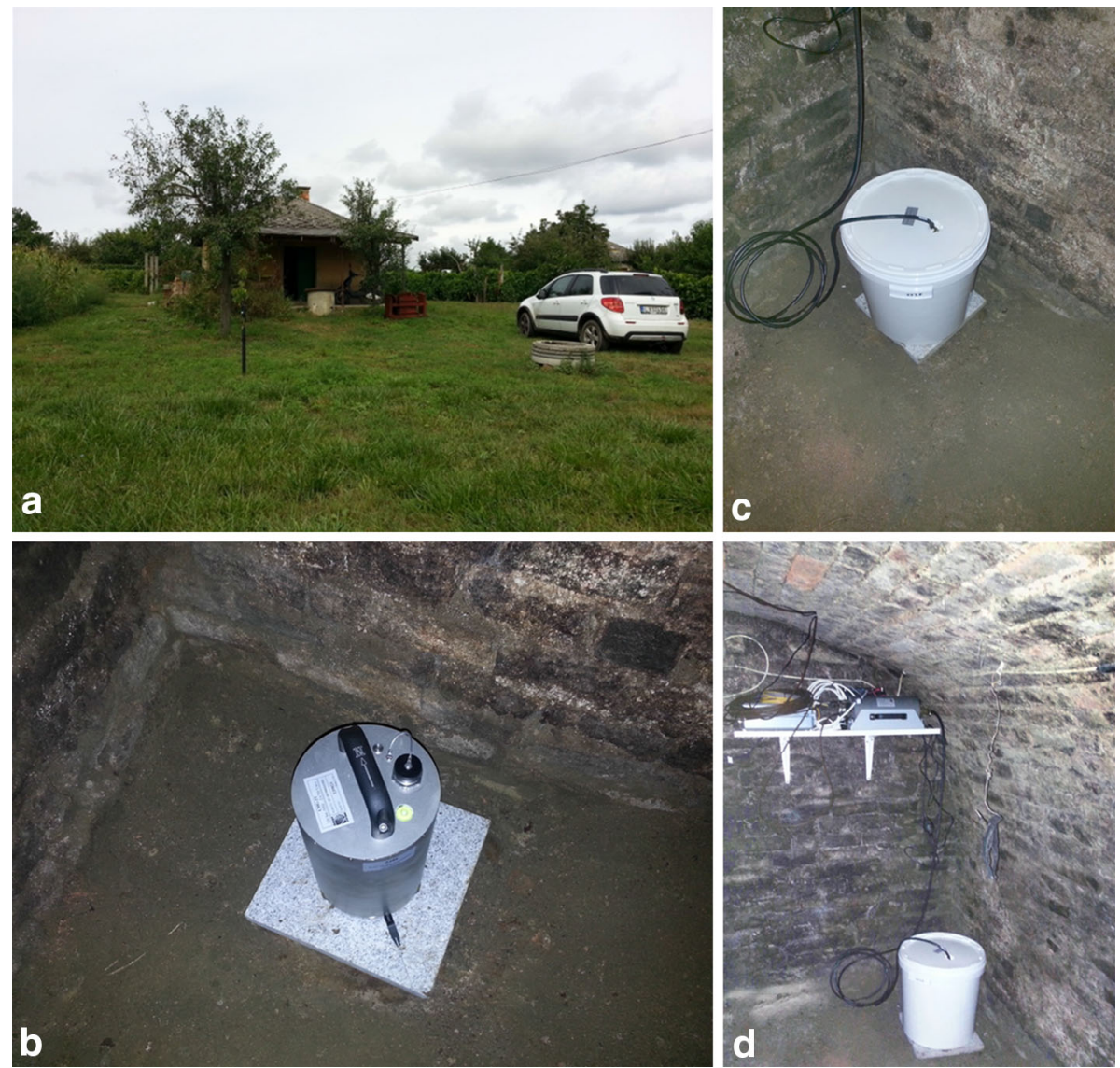

Fig. 2 A typical station configuration for the AlpArray project. a The selected one-storey building for station A267A. b Sensor after levelling and orientation with magnetic compass. North direction is marked on the granite slab. $\mathbf{c}$ For thermal insulation the sensor is covered with a pail filled with polystyrene packing foam peanuts. d The installed station. GPS antenna is mounted through the vent chimney. (Color figure online) 
by a pail filled with polystyrene packing foam peanuts. Each station is connected to the power grid system. Batteries provide $12 \mathrm{~V} \mathrm{DC}$ required for the operation of the instruments, and at the same time they ensure continuous data recording in case of power outages. Real-time data access is realized through wired or $3 \mathrm{G}$ mobile network connection. All the stations use GPS timing.

Between 20th March and 20th April 2017 we measured the orientation of the sensors of permanent and temporary stations using an iXblue Quadrans fiber-optic gyrocompass (kindly provided by the Institute of Geophysics, Czech Academy of Sciences). The orientation values can be seen in Tables 1 and 2. The seismometers of the stations LTVH and PSZ were not on their plinth during the measurement period, so in these cases only the north line was drawn and during their relocations the sensors were oriented according to these lines. Therefore the $0.0^{\circ}$ values for these stations in Table 1 are valid only for the post-measurement period. In the case of A265A the owner of the station's building was not available, thus we could not perform the measurement. This lack of data is indicated by NA in Table 2. The measured orientations range between $-14.6^{\circ}$ and $18.9^{\circ}$, the deviation from the north was smaller than $6^{\circ}$ for 14 stations from the measured 26. It is important to note that the sensors were not reoriented after the gyrocompass measurements, but the orientation information has been added to the stations' metadata.

\section{Data acquisition}

The real-time data are acquired in miniSEED format by the KRSZO using the SeisComp3 software package (http://www.seiscomp3.org). The sampling frequency is set to $100 \mathrm{~Hz}$. The collected data of the HNSN permanent stations are archived at the GEOFON EIDA node, while the ORFEUS EIDA node stores the data of the Hungarian AlpArray temporary stations. The waveform data from the permanent stations are openly available through EIDA, however at the present time the data from the AlpArray temporary stations are restricted to the Core Group members of the AlpArray project. The details of the data access policy can be found at the AlpArray website (http://www.alparray.ethz.ch/seismic network/backbone/data-access/).

\section{Site characteristics}

In this section we introduce each station, describing the location, housing type, site geology and seismic noise characteristics. Station names, locations, coordinates, equipment, beginning of operation, orientation of sensors and the type of geological environment are summarised in Tables 1 and 2 .

Geological descriptions are based on the Pre-Cenozoic geological map of Hungary by Haas et al. (2010) and the Geological map of Hungary by Gyalog (2013) available at the http://map.mbfsz.gov.hu website.

The noise characteristics of the stations are discussed based on the results of power spectral density (PSD) computations whose details are presented in Sect. 8. 


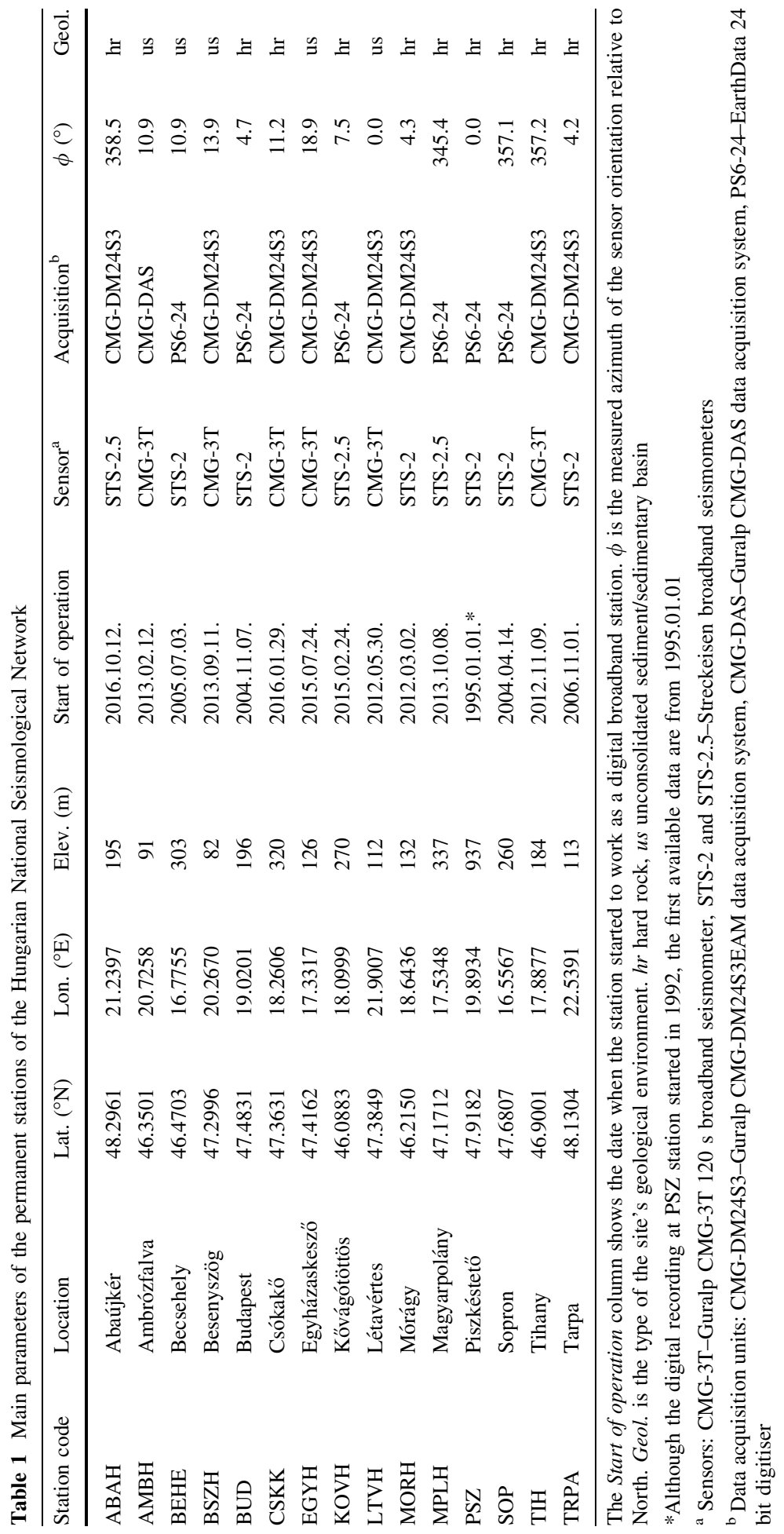




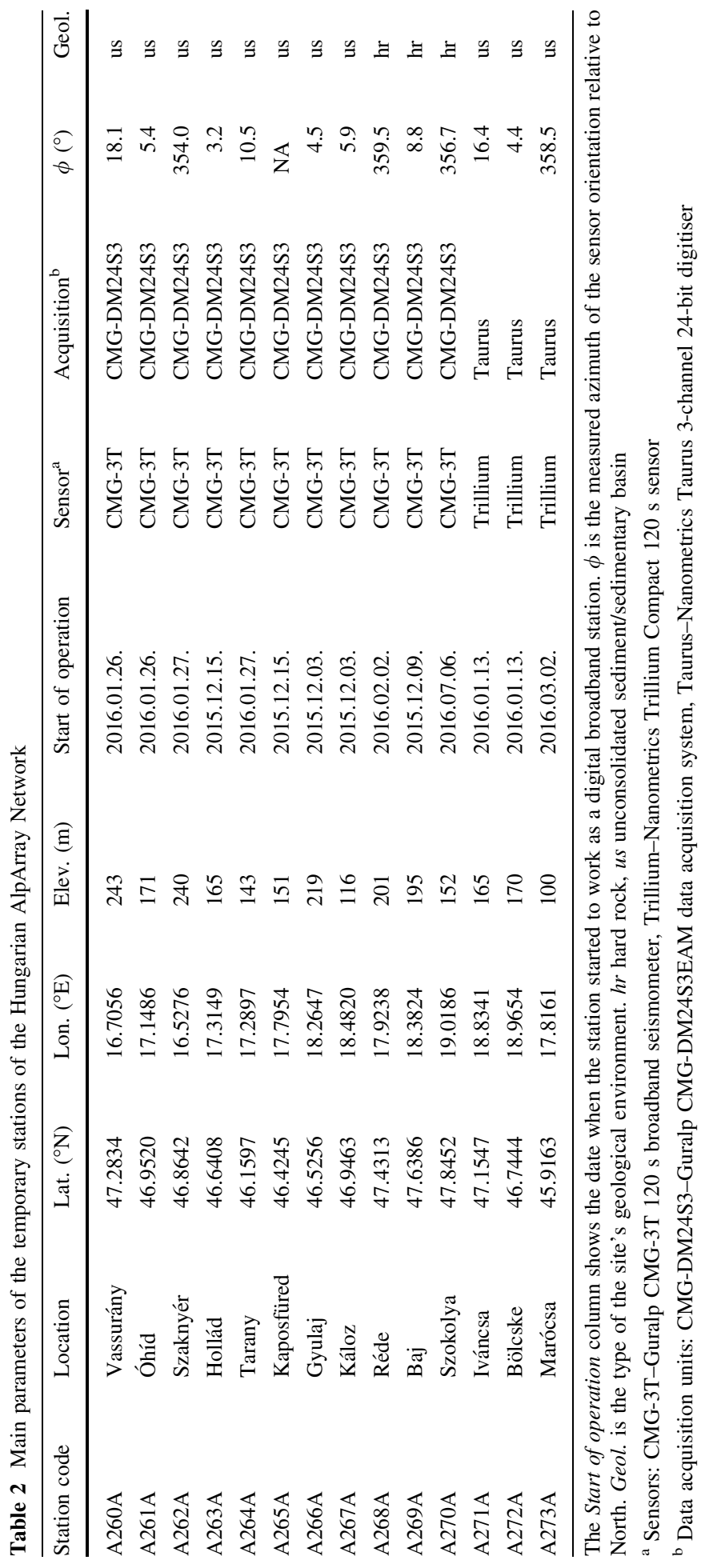




\subsection{Site characteristics of the permanent stations}

\subsubsection{ABAH-Abaújkér}

Station ABAH is located in the administrative area of the village Abaújkér, at the eastern part of the North Hungarian Range (Zemplén Mountains). The pre-Cenozoic basement is at $2 \mathrm{~km}$ depth, on the surface Middle Miocene pyroxene andesite and its pyroclastics can be found. The station has been deployed in a cellar which belongs to a hotel in the middle of a forest, approximately $1 \mathrm{~km}$ from the nearest settlement. The cellar is carved into a cliff, where the sensor was installed directly on rock. There is a low traffic local road $40 \mathrm{~m}$ from the station and the distance to the hotel's main building is $30 \mathrm{~m}$. The median power spectral density curves in the short and long period ranges are well below the $-20 \mathrm{~dB}$ noise level for both the vertical and horizontal components, except for the horizontal components at long periods where they run above the $-10 \mathrm{~dB}$ curve.

\subsubsection{AMBH-Ambrózfalva}

Ambrózfalva is a village in the Great Hungarian Plain, close to the Hungarian-Romanian border in south Hungary, where more than $2 \mathrm{~km}$ thick sediments cover the basement and Upper-Pleistocene loess is on the surface. The station was deployed at the funeral home in the cemetery located at the edge of the village. The sensor is placed on the concrete floor. There is a low traffic local road around $40 \mathrm{~m}$ from the station and the distance to the nearest buildings is larger than $100 \mathrm{~m}$. At short periods the vertical and horizontal noise is high due to the sedimentary environment, but the PSD curves stay below the NHNM. In the long period range the median PSD curves for the horizontal components run along the NHNM, the vertical noise curve lies in the middle of the NLNM-NHNM range, below the $-20 \mathrm{~dB}$ level.

\subsubsection{BEHE-Becsehely}

Station BEHE is located at a hilltop $2 \mathrm{~km}$ from the residential area of Becsehely. The basement is approximately at $4.5 \mathrm{~km}$ depth and the surface is covered by Upper Pleistocene eolian brown loess. The equipment is placed in a one-storey adobe building in a sparsely built area with fruit gardens and vineyards. The floor is made of concrete, the sensor was installed directly on it. The possible noise sources are a $20 \mathrm{~m}$ high antenna and a very low traffic local road, both roughly in $20 \mathrm{~m}$ radius of the sensor. The short period vertical and horizontal noise is high, the median PSD curves run $-10 \mathrm{~dB}$ below the NHNM level. In the long period range the vertical noise is satisfactory, while the horizontal median PSD curve is well above the NHNM. This extreme horizontal noise can be probably explained by the presence of the antenna.

\subsubsection{BSZH-Besenyszög}

Besenyszög lies on a $4 \mathrm{~km}$ thick sedimentary cover sequence in the northern central part of the Great Hungarian Plain, where Holocene fluvial silt and clay are observed on the surface. Station BSZH has been deployed in the basement of a chapel at the village cemetery inside the residential area. The equipment was placed on a concrete plinth. The distance of the nearby dwelling houses is larger than $50 \mathrm{~m}$. The short period vertical and 
horizontal noise is very high due to the young, unconsolidated sediments and the surrounding residential area, the median PSD curves run along the NHNM. In the long period range the median PSD curves for the horizontal components are above the NHNM by around $10 \mathrm{~dB}$. This high noise level is possibly due to the ground tilt caused by the tower of the chapel. The vertical noise curve runs much lower, it is close to the $-20 \mathrm{~dB}$ level.

\subsubsection{BUD-Budapest}

Station BUD is located in the city of Budapest, near the building of the KRSZO. The sensor is placed on a concrete plinth in an underground tunnel carved into Upper Triassic dolomite. The room hosting the seismometer is approximately $20 \mathrm{~m}$ beneath the surface. The territory belongs to a nature reserve, the nearest residential buildings are more than 60 $\mathrm{m}$ away from the station. The distance of the closest street is around $70 \mathrm{~m}$ and there is a very high traffic road at $400 \mathrm{~m}$ and a busy railway line at $600 \mathrm{~m}$ from the station. For the short periods the vertical and horizontal PSD curves are below the $-10 \mathrm{~dB}$ level. At the long period range, the vertical median PSD curve is between the -20 and $-10 \mathrm{~dB}$ levels, while the curves belonging to the horizontal components are below the $-20 \mathrm{~dB}$ level.

\subsubsection{CSKK-Csókakö}

Station CSKK is located in the Vértes Mountains. The sensor is deployed in the basement of a two-storey cottage which is built upon Upper Triassic limestone. The building can be found at the remote peripheral part of the village of Csókakő. Potential noise sources are a nearby low traffic road, a heavy traffic secondary road $2.8 \mathrm{~km}$ far away and a large forested area towards NE of the station. Until January 2016 CSKK had been working as a short period station, since then a broadband sensor has been operating which is placed on a granite slab. The noise level is satisfactory both on the vertical and horizontal components regarding the short period range, and on the vertical component in the case of long periods. Above $20 \mathrm{~s}$, the horizontal median PSD curves approach from below the NHNM.

\subsubsection{EGYH-Egyházaskeszö}

Egyházaskesző is a village at the southern part of the Little Hungarian Plain. It is situated approximately $2.2 \mathrm{~km}$ from the Rába River, the thickness of the sedimentary cover exceeds $2 \mathrm{~km}$. The area is flat and Upper Pleistocene gravel is on the surface. The station is installed at the eastern edge of the village, in the basement of a nursery school. The sensor is placed on a concrete floor. The short period vertical and horizontal noise is relatively high, but the median PSD curves lie below the $-10 \mathrm{~dB}$ level. In the long period range the horizontal noise median PSD curves run close, but below the NHNM, the vertical noise curve is well below the $-20 \mathrm{~dB}$ level.

\subsubsection{KOVH-Kövágótöttös}

Kővágótöttös is a small village in the southern part of the Mecsek Mountains. Station $\mathrm{KOVH}$ is located in the centre of the residential area beneath the local council building in a cellar which is carved into Upper Permian-Lower Triassic sandstone. The sensor is placed on a concrete plinth. Despite being in the centre of the village, the nearby traffic is light, however there is a very high traffic primary road in $3.3 \mathrm{~km}$ distance that might influence 
the noise level. The median PSD level is rather close to the low noise model both on the vertical and horizontal components regarding the short period range, and on the vertical component for long periods. Above $20 \mathrm{~s}$, the horizontal median PSD curves approach from below the $-10 \mathrm{~dB}$ level.

\subsubsection{LTVH-Létavértes}

Station LTVH is installed in the cemetery of Létavértes, a village in eastern Hungary, close to the Hungarian-Romanian border. The settlement lies on $3.5 \mathrm{~km}$ thick sediments with Upper Pleistocene loess on the surface. The cemetery is located at the edge of the village, the distance to the nearby residential houses is larger than $200 \mathrm{~m}$. The station has been deployed in a vault, the sensor was placed on a concrete plinth. LTVH can be described by high noise levels (the maximum is somewhat below the NHNM curve) both on the vertical and horizontal components, the only exception is the long period range on the vertical component where the median PSD curve is below the $-20 \mathrm{~dB}$ level. The short period noise characteristics at LTVH are very similar to that of the other two stations (AMBH, BSZH) deployed on soft sediments in the territory of the Great Hungarian Plain.

\subsubsection{MORH-Mórágy}

Mórágy is a village in the Mecsek Mountains. The MORH station is deployed in its residential area in a cellar which is carved into a cliff consisting of Paleozoic granite. The sensor is placed on a concrete plinth. The site is surrounded by only a few houses (their distance is larger than $70 \mathrm{~m}$ ) and the local area is characterized by little traffic, however there is a highway at $4.4 \mathrm{~km}$ distance. To the east of the station a forest can be found. MORH can be considered as the best seismic station in Hungary, the noise level is satisfactory at all periods. In the long period range the vertical component noise is very low, its median PSD curve runs along the NLNM exceeding it by only around $5 \mathrm{~dB}$.

\subsubsection{MPLH-Magyarpolány}

The village of Magyarpolány is located at the northern margin of the Transdanubian Central Range, where Middle Eocene limestones outcrop. The MPLH station is situated outside the residential area (its distance $>400 \mathrm{~m}$ ), on a hillside where traffic is negligible. The closest primary road lies at a distance of $3.6 \mathrm{~km}$. A two-storey building hosts the equipment, where the sensor is placed on the concrete floor of the ground level. The noise level is satisfactory on the vertical and horizontal components in the short period range. At long periods the vertical noise is of low level, the horizontal component curves run below the NHNM level by $5-10 \mathrm{~dB}$.

\subsubsection{PSZ-Piszkéstetö}

PSZ was the first digital seismological station in Hungary. It is located in the Mátra Mountains (North Hungarian Range) at $940 \mathrm{~m}$ altitude where Middle Miocene pyroxene andesite is on the surface. The equipment is placed in the middle of a forest in the basement of a stand-alone one-storey building belonging to the Piszkésteto" Mountain Station of the MTA CSFK CSI Konkoly Observatory. The sensor was installed on a concrete plinth. The area is closed to the public, so the traffic is insignificant, the nearest 
low traffic road is at $500 \mathrm{~m}$ distance. PSZ is one of the best stations in Hungary, the noise level is satisfactory at all periods. In the long period range the vertical component noise is very low, its median PSD curve runs above the NLNM at a distance around 5-10 dB. On the horizontal components at long periods the PSD curves are below the NHNM level by $20-25 \mathrm{~dB}$.

\subsubsection{SOP-Sopron}

The sensor of station SOP has been deployed on a concrete plinth in the basement of the MTA CSFK GGI Geodynamic Observatory in Sopronbánfalva located in the Sopron Hills. The Observatory lies at the foot of a cliff, where Paleozoic gneiss outcrops. The area is inside the city of Sopron, however the nearest houses are $70 \mathrm{~m}$ to the west and much further in every other directions. A railway line runs approximately $900 \mathrm{~m}$ away from the station. Although the noise characteristics of SOP can be generally considered satisfactory except a narrow period range at around $0.7 \mathrm{~s}$ on the horizontal components, the short period noise levels are not particularly low because of the surrounding city. At long periods the horizontal PSD curves lie more than $20 \mathrm{~dB}$ below the NHNM level and the vertical noise is one of the lowest among the Hungarian stations.

\subsubsection{TIH-Tihany}

Tihany peninsula is situated at the northern shore of Lake Balaton. The TIH station was deployed in a one-storey building belonging to the research area of the Tihany Geophysical Observatory located at a hillside at the south-eastern part of the peninsula, where basaltic pyroclasts and geyserite are on the surface. This station is operated in cooperation with the Mining and Geological Survey of Hungary. The building itself serves only for geophysical measurements, the equipment is placed on the concrete floor. The area is sparsely built without a main road in the vicinity (the distance of a low traffic local road is $250 \mathrm{~m}$ ), the nearest houses are at least $100 \mathrm{~m}$ away. The site is $750 \mathrm{~m}$ from the shore and is bordered by a forest from the north. The short period vertical and horizontal noise is high, in the 0.3-0.8 s period range the median PSD curves run just below the NHNM. In the long period range the horizontal noise median PSD curves are below the NHNM level by around $10 \mathrm{~dB}$, the vertical noise curve lies somewhat below the $-20 \mathrm{~dB}$ curve. The unsatisfactory noise characteristics of the station can probably be attributed to the proximity of Lake Balaton.

\subsubsection{TRPA-Tarpa}

Station TRPA is the easternmost station in Hungary, it is located close to the HungarianUkrainian border. The equipment is placed in the basement of a rarely used one-storey building outside the village of Tarpa, in an area of vineyards and fruit gardens. There is a low traffic road at $150 \mathrm{~m}$, the Tisza river flows $4.5 \mathrm{~km}$ from the station. The sensor was installed on a concrete plinth. Although the pre-Cenozoic basement is generally at $3 \mathrm{~km}$ depth in the area, beneath the station's surroundings a volcanic body is buried under the younger sediments with sporadic dacite outcrops. The station itself is located approximately $600 \mathrm{~m}$ from these outcrops. Right at the station, however, the surface is covered by Upper Pleistocene loess and Holocene fluvial clay. The noise level is satisfactory on the vertical and horizontal components in the short period range, the median PSD curves run 
more than $20 \mathrm{~dB}$ below the high noise model. At long periods the vertical noise is of rather low level, the horizontal component curves lie along, but below the NHNM curve.

\subsection{Site characteristics of the temporary stations}

\subsubsection{A260A-Vassurány}

Vassurány is a village at the south-western edge of the Little Hungarian Plain where the pre-Cenozoic basement is at $2 \mathrm{~km}$ depth. The surface is covered by upper Pleistocene brown loess. Station A260A is located inside the residential area of Vassurány. It was deployed on the ground level in a two-storey building which is part of a larger complex for agricultural usage. The sensor was put on the concrete floor. Large machinery movements are frequent in the vicinity of the station. The short period vertical and horizontal noise is high, the median PSD curves approach the NHNM level to around $5 \mathrm{~dB}$. In the long period range the horizontal noise median PSD curves exceed the high noise model by more than $10 \mathrm{~dB}$, the vertical noise curve is satisfactory, it is above the low noise model by around $20 \mathrm{~dB}$. The strong long period horizontal noise is probably caused by ground tilt of unknown origin.

\subsubsection{A261A-Óhíd}

Station A261A is deployed outside the residential area of Óhíd, a village located north to the Keszthely Mountains, at the north-western end of the Transdanubian Central Range. The pre-Cenozoic basement is at $1 \mathrm{~km}$ depth, the surface is covered by upper Pleistocene loess. The equipment is placed on a granite slab in a concrete vault close to a rarely used one-storey building. The site is situated on an agricultural land relatively far from the residential area (distance $>1 \mathrm{~km}$ ). The nearest, low traffic road is at a distance of $1 \mathrm{~km}$. Although the short period vertical and horizontal noise is high, the median PSD curves are below the $-10 \mathrm{~dB}$ zone. In the long period range the horizontal noise median PSD curves run below the high noise model, but its distance is less than $10 \mathrm{~dB}$; the vertical noise curve is one of the best among the Hungarian temporary AlpArray stations.

\subsubsection{A262A-Szaknyér}

Szaknyér is a small village close to the Hungarian-Austrian-Slovenian border. The preCenozoic basement is at $3 \mathrm{~km}$ depth and the surface is covered by upper Pleistocene deluvial sediments. Station A262A was deployed in a two-storey belfry. The sensor has been installed on the concrete floor of the ground level. The short period vertical and horizontal noise median PSD curves are below the $-10 \mathrm{~dB}$ level. In the long period range the horizontal noise median PSD curves run $10 \mathrm{~dB}$ above the high noise model (which is probably due to the belfry tower-wind interaction); the vertical noise curve is satisfactory.

\subsubsection{A263A-Hollád}

Station A263A is located in a relatively shallow, $1 \mathrm{~km}$ deep sedimentary basin filled with Cenozoic sediments, $8 \mathrm{~km}$ distance from Lake Balaton. The surface is covered by Pleistocene brown loess. The station has been deployed outside the residential area of Hollád (distance $>300 \mathrm{~m}$ ), in the funeral home of the cemetery where the sensor is placed on a 
tiled floor. There is a primary road at $850 \mathrm{~m}$ and a highway at $1.5 \mathrm{~km}$ distance. The vertical and horizontal PSD curves both at short and long periods are below the NHNM.

\subsubsection{A264A-Tarany}

Station A264A is located outside the residential area of Tarany in the middle of an agricultural land. The pre-Cenozoic basement is at $3.5 \mathrm{~km}$ depth and upper Pleistocene sand can be found on the surface. The equipment is placed in a concrete vault, next to a one-storey building which is used for distillery. The sensor was installed on a concrete plinth. The station is surrounded by trees and at a distance of $1.1 \mathrm{~km}$ a chain of fishponds is situated. Both the vertical and horizontal median PSD curves are below the NHNM, except the horizontal components at long periods where the PSD curves run along the high noise level.

\subsubsection{A265A-Kaposfüred}

Kaposfüred is a village lying $5 \mathrm{~km}$ north from the city of Kaposvár. The basement depth exceeds $2 \mathrm{~km}$ and the area is covered by Upper Pleistocene loess. Station A265A is located in a sparsely built area within a distance of $350 \mathrm{~m}$ from a relatively large water reservoir. The equipment is placed in the basement of a one-storey building, where the sensor was put on a granite slab. The nearest, secondary road is at $1.2 \mathrm{~km}$. The vertical and horizontal PSD curves both at short and long periods are below the NHNM.

\subsubsection{A266A-Gyulaj}

Station A266A is located at a region where the pre-Cenozoic basement is approximately at $1 \mathrm{~km}$ depth and the surface is covered by Upper Pleistocene loess. It was deployed in a wild animal processing facility associated with hunting. The building complex is surrounded by a forest and it is primarily used in hunting season. The equipment was placed in an unused cellar. The sensor was installed on a concrete plinth. At short periods for all components the PSD curves are below the $-10 \mathrm{~dB}$ level, at long periods the vertical component runs $20 \mathrm{~dB}$ above the NLNM, while the horizontal components exceed the NHNM.

\subsubsection{A267A-Káloz}

Station A267A is located outside the residential area of the village of Káloz (distance > $350 \mathrm{~m}$ ), where fruit gardens and vineyards can be found. The pre-Cenozoic basement is at $1.5 \mathrm{~km}$ depth and the surface is covered by Upper Pleistocene sand. The equipment is installed in the basement of a rarely used wine press house (Fig. 2). The sensor was put on a granite slab which is placed on the sandy floor. There is a low traffic local road at $500 \mathrm{~m}$ and a secondary road at $1 \mathrm{~km}$ distance. The vertical and horizontal PSD curves both at short and long periods are below the NHNM.

\subsubsection{A268A-Réde}

Réde is a village at the northern margin of the Transdanubian Central Range. Station A268A is located in a cemetery at the north-western edge of the settlement. The equipment 
is placed in a rarely used room of the one-storey funeral home where the sensor was installed on the tiled floor. The pre-Cenozoic basement is at approximately $100 \mathrm{~m}$ depth, the wider area is covered by various sediments: Holocene alluvium, upper Pleistocene sand and Oligocene clay. Due to the relatively thin sedimentary cover the noise levels are lower than for the typical AASN stations installed in basin areas, the short period vertical and horizontal noise curves run along the $-20 \mathrm{~dB}$ level. The long period characteristics however do not differ significantly from stations installed in deeper basins.

\subsubsection{A269A-Baj}

Station A269A is deployed at the western foot of the Gerecse Hills (part of the Transdanubian Central Range). The station is located at a sparsely built vineyard outside the residential area of Baj, but it is only approximately $1.8 \mathrm{~km}$ away from one of the busiest main railway lines in Hungary, including passenger and cargo transport. Additionally, there is a primary road at $1 \mathrm{~km}$ and a highway in $3.5 \mathrm{~km}$ distance. The equipment was deployed in a rarely used one-storey cottage built on top of a thin cover of Upper Pleistocene loess overlying Upper Triassic limestone. The sensor was put on a granite slab placed on the sandy floor in the basement of the building. At short periods the vertical and horizontal PSD curves lie below the $-10 \mathrm{~dB}$ level. The vertical, long period noise is one of the best between the Hungarian AlpArray stations, the horizontal curves approach from below the NHNM.

\subsubsection{A270A-Szokolya}

The village of Szokolya is located near the Danube Bend in a wooded area where Miocene dacite is on the surface. Station A270A has been deployed in the basement of a one-storey house. The sensor was placed on a granite slab. A low traffic road and a small train railway line is within $100 \mathrm{~m}$ distance, a secondary road and a main railway line lies at $2 \mathrm{~km}$, while the Danube flows approximately $2.6 \mathrm{~km}$ from the station. A270A is the best temporary AlpArray station. The short period vertical and horizontal noise levels are below the $-20 \mathrm{~dB}$ level, and the long period vertical noise is the lowest among the temporary stations. The long period horizontal PSD curves run between the NHNM and the $-10 \mathrm{~dB}$ level.

\subsubsection{A271A-Iváncsa}

Station A271A was deployed outside the residential area of Iváncsa, a village at the right side of the Danube south to Budapest. The equipment is in a funeral home, where the sensor was installed on tiles. The station is located approximately $2.7 \mathrm{~km}$ west of the Danube. At $2.2 \mathrm{~km}$ west of the village a highway, toward east a high traffic primary road at $2 \mathrm{~km}$ and a busy railway line at $2.8 \mathrm{~km}$ can be found. The pre-Cenozoic basement is at $3.5 \mathrm{~km}$ depth and the surface is covered by upper Pleistocene sandy loess. The vertical and horizontal PSD curves both at short and long periods are below the NHNM.

\subsubsection{A272A-Bölcske}

Bölcske is a village $1.3 \mathrm{~km}$ west of the Danube, where the pre-Cenozoic basement is at less than $500 \mathrm{~m}$ depth and Middle to Upper Pleistocene loess covers the surface. Station A272A 
has been deployed in a cellar at the edge of the village. The sensor is placed on the concrete floor. A primary road is within $6 \mathrm{~km}$ distance to the station and a highway runs $7 \mathrm{~km}$ east of it. The vertical and horizontal PSD curves both at short and long periods are below the NHNM.

\subsubsection{A273A-Marócsa}

Marócsa is a village near the southern border of Hungary. The pre-Cenozoic basement is at $1.5 \mathrm{~km}$ depth, the surface is covered by upper Pleistocene and Holocene fluvial sediments. Station A273A has been deployed outside the residential area of Marócsa, in the funeral home of the cemetery. The nearest houses are in $100 \mathrm{~m}$ distance. A railway line runs $2.8 \mathrm{~km}$ west of the station. The sensor was placed on the tiled floor. Station A273A has practically the worst noise levels in the short period range both on the vertical and horizontal components, but the curves still are below the NHNM level. It has one of the highest long period vertical component noise together with stations A271A and A272A among the temporary stations (however the curves are still under the $-20 \mathrm{~dB}$ level). The long period horizontal noise PSD curves are slightly below the NHNM level.

\section{Noise characteristics of the Hungarian National Seismological Network}

Power spectral density plots (McNamara and Buland 2004) were computed for all stations of the HNSN using 1 year long data (collected between 2016.08.01 and 2017.07.31). The computations were performed using the Obspy library (Beyreuther et al. 2010; Krischer et al. 2015).

From the PSD data we computed median noise curves. The results for the vertical and horizontal $(\mathrm{N})$ components are shown in Figs. 3 and 4. The NHNM and NLNM curves correspond to the New High and New Low Noise Models of Peterson (1993). The dark and light gray zones show the noise levels which lie between the NHNM and NHNM-10 dB, and between the NHNM-10 dB and NHNM-20 dB curves, respectively.

\subsection{Vertical component noise}

The vertical component median PSD curves for the HNSN permanent and temporary AlpArray stations are shown in Fig. 3a and b. It must be noted that for every station the curves are below the NHNM level.

Based on the AlpArray Seismic Network quality requirements (see in Sect. 4) and the observed noise characteristics, it is worth dividing the period range into three parts. For periods less than 1-2 s, the majority of the PSD curves belonging to the permanent stations are below the $-10 \mathrm{~dB}$ level (Fig. 3a), they exceed it only at four stations (AMBH, BSZH, LTVH, TIH - which are deployed in deep sedimentary basins with the exception of TIH lying next to Lake Balaton). Further four stations (BEHE, BUD, EGYH, SOP) are in the zone between the -10 and $-20 \mathrm{~dB}$ levels. The remaining stations have favourable short period noise characteristics, they median PSD curves run under the $-20 \mathrm{~dB}$ level. For the period range between 2 and $20 \mathrm{~s}$, all the PSD curves lie below the $-20 \mathrm{~dB}$ level, and they run together in a band narrower than $20 \mathrm{~dB}$. For periods longer than $20 \mathrm{~s}$, only two PSD curves (BUD, BSZH) run above the $-20 \mathrm{~dB}$ level. 

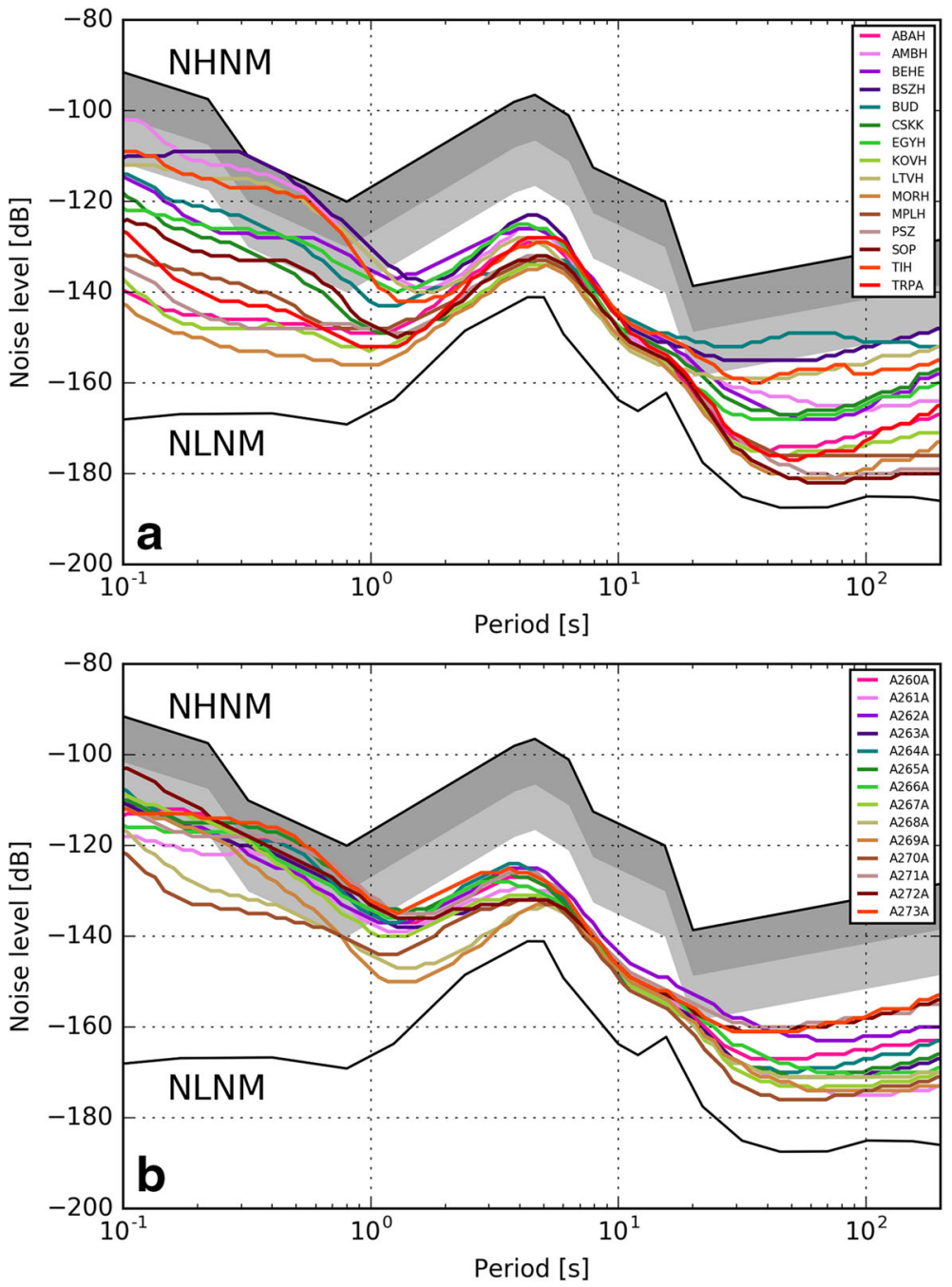

Fig. 3 Vertical component median power spectral density (PSD) curves a for the permanent stations of the Hungarian National Seismological Network and $\mathbf{b}$ for the temporary AlpArray stations. The vertical axis shows the noise level in $\mathrm{dB}$ relative to $1\left(\mathrm{~m} / \mathrm{s}^{2}\right)^{2} / \mathrm{Hz}$. NHNM: New High Noise Model, NLNM: New Low Noise Model (Peterson 1993); dark gray zone: noise levels between NHNM and NHNM-10 dB; light gray zone: noise levels between NHNM-10 dB and NHNM-20 dB. (Color figure online)

In the case of the temporary AlpArray stations (Fig. 3b), in the short period range (under 1-2 s) the noise characteristics are considerably worse than for most permanent stations. This is due to the fact that most of the temporary stations are deployed in sedimentary basins. All stations but two (A268A, A270A - which are installed on rock outcrops, therefore have better noise characteristics) are in the zone between the $-20 \mathrm{~dB}$ and NHNM levels. Between 2 and 20 s periods, as for the permanent stations, all PSD curves are below the $-20 \mathrm{~dB}$ level. For the range above $20 \mathrm{~s}$, only an insignificant portion of $2-3$ curves are above the $-20 \mathrm{~dB}$ level. 

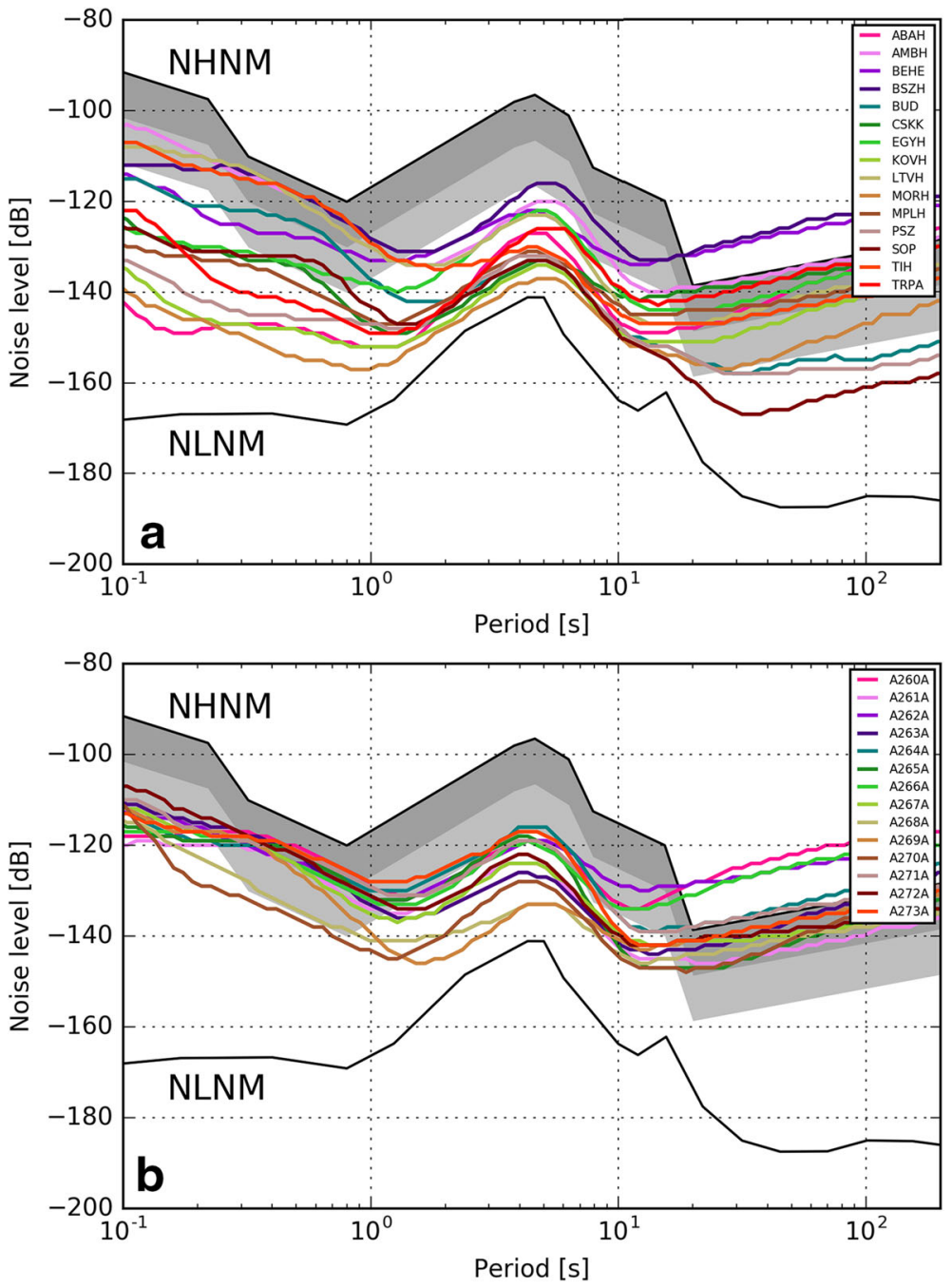

Fig. 4 Horizontal (N) component median power spectral density (PSD) curves a for the permanent stations of the Hungarian National Seismological Network and b for the temporary AlpArray stations. For explanations of the abbreviations and markings, see Fig. 3. (Color figure online)

As a summary, it can be concluded that the stations of the Hungarian National Seismological Network have satisfactory vertical noise levels with only two exceptions; every temporary AlpArray station and 13 out of 15 permanent stations meet the AASN noise requirements.

\subsection{Horizontal component noise}

For the description of the horizontal noise characteristics the north-south component has been chosen. The corresponding PSD curves for the HNSN permanent and temporary AlpArray stations are shown in Fig. 4a and b, respectively. 
In the case of the permanent stations at short periods only six PSD curves (belonging to stations deployed on rock: ABAH, KOVH, MORH, MPLH, TRPA, PSZ) run below the $-20 \mathrm{~dB}$ level and there are four stations (AMBH, BSZH, LTVH, TIH) where the curves are above the $-10 \mathrm{~dB}$ line. In this period range there is no station whose PSD curve is above the high noise level. For periods between 2 and $10 \mathrm{~s}$, all but three PSD curves (AMBH, BEHE, BSZH) are below the $-20 \mathrm{~dB}$ level. In the long period range there are only three stations (BUD, PSZ, SOP) whose noise is lower than the $-20 \mathrm{~dB}$ level (these stations are deployed in cellars carved in rocks). The majority of the PSD curves are located between the NHNM and $-10 \mathrm{~dB}$ levels. There are two stations (BEHE, BSZH) whose horizontal noise levels are significantly worse than the high noise model.

For the AlpArray stations in the sort period range there is only one station (A270A) whose PSD curve is clearly below the $-20 \mathrm{~dB}$ level. It must be noted that in this period range the most PSD curves run rather close to each other. They approach most closely the high noise model at periods $0.2-1 \mathrm{~s}$. Between 2 and $10 \mathrm{~s}$, all the curves are below the $-10 \mathrm{~dB}$ level and most of them are even below the $-20 \mathrm{~dB}$ level.

In the long period range (above $20 \mathrm{~s}$ ) there are three PSD curves (A260A, A262A, A266A) significantly above the high noise model, the remaining eleven are practically located between the NHNM and $-10 \mathrm{~dB}$ levels.

In order to be able to evaluate the horizontal noise levels in the light of the requirements, we have to treat the noise levels for short and long periods separately. The noise levels in the short period range comply with the requirements for all stations of the temporary and permanent networks. However, the situation is completely different for the horizontal long period noise. The criteria are met only for 8 stations out of 15 in the case of the permanent stations, and for another 8 cases among 14 temporary stations.

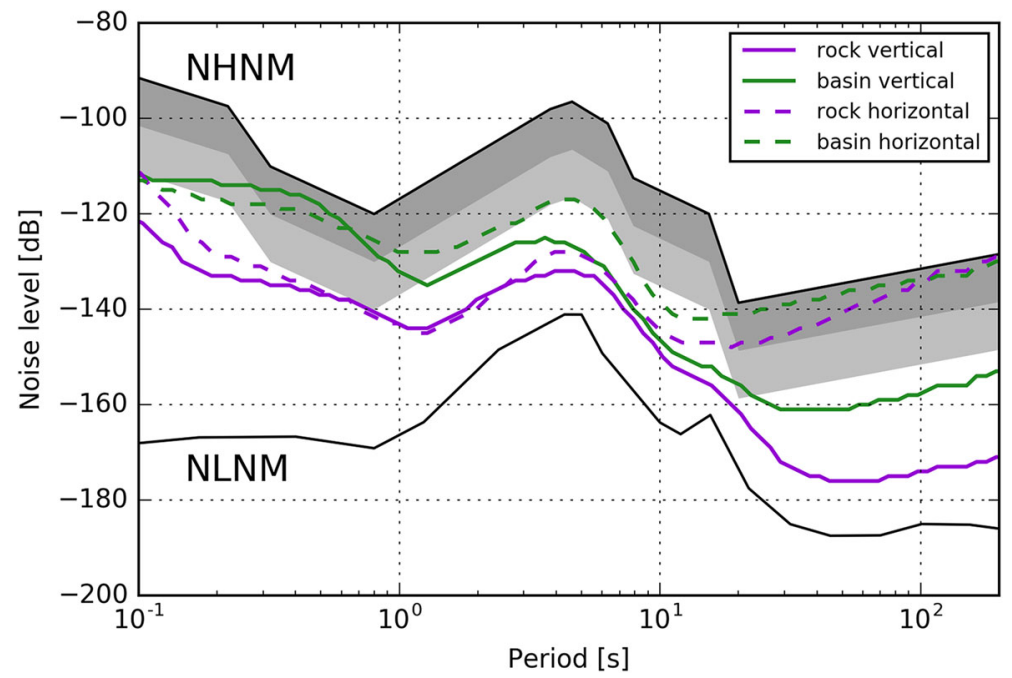

Fig. 5 Average of the vertical and horizontal component median power spectral density curves for the Hungarian stations deployed on rocks (violet) and in sedimentary basins (green). For explanations of the abbreviations and markings, see Fig. 3. (Color figure online) 


\subsection{Average noise in different geological environments}

It is worth comparing the average noise characteristics of the stations deployed on hard rock and in sedimentary basins with usually thick Cenozoic unconsolidated sediments. In Fig. 5 we present the averaged median PSD curves for these two types of station locations. It can be seen that the vertical PSD curve for the stations installed on hard rock is below the $-20 \mathrm{~dB}$ level for every period. The averaged vertical noise curve for the sedimentary basin sites, however, runs higher in the whole period range, the largest separation can be observed at short and long periods where the difference can reach values of around $20 \mathrm{~dB}$.

Considering the horizontal components, we find that at periods less than $10 \mathrm{~s}$ the rock site average PSD curve runs below the $-20 \mathrm{~dB}$ level and almost in the whole period range the basin sites can be characterised by higher noise. The maximum separation of basin and rock horizontal PSD curves is around $20 \mathrm{~dB}$ and this value is characteristic for shorter periods. In the case of longer periods the difference is considerably smaller and both curves approach the NHNM from below.

It is worth comparing the average vertical and horizontal PSD curves for the different site types. For periods shorter than $10 \mathrm{~s}$ the difference between the vertical and horizontal curves is not significant for both types of sites, however for the longer periods it grows excessively, in the case of the rock sites it even reaches a value of around $40 \mathrm{~dB}$.

\section{Conclusions}

We have installed 14 new temporary online broadband stations in the territory of WesternHungary. Eleven stations were financially supported by the Hungarian Academy of Sciences, three station equipment were provided by the Swiss-AlpArray SINERGIA program. The AlpArray project officially started on 1 January 2016, the planned operating period of the stations is 3 years. By the beginning of March 2016 thirteen temporary stations had been already deployed, while the last station was installed in July 2016.

During the deployments of the temporary stations we closely followed the guidelines of the AlpArray Technical Strategy. The final sites are within the $6 \mathrm{~km}$ radius of the planned station locations. Every station is equipped with online broadband sensors, the sampling rate is $100 \mathrm{sps}$ and for the timing we use GPS receivers. The data of both the permanent and temporary stations are collected by the EIDA.

Using the data of 1 year operation we examined the noise performance both of the permanent and temporary stations. According to the power spectral density computations the noise on the vertical and the short period horizontal components typically meet the requirements, but this is not the case regarding the long period horizontal noise. These experiences are mostly consistent with the observations made during the AlpArray station deployments in Austria (Fuchs et al. 2015), Italy (Govoni et al. 2017), Switzerland (Molinari et al. 2016) and the Czech Republic (Vecsey et al. 2017).

Despite the fact that most of the Hungarian stations are located in sedimentary basins, the measured noise levels meet the criteria reasonably well. Therefore the network as a whole will certainly provide the necessary information to address each of the scientific objectives outlined in Sect. 2 and the research activities related to the AlpArray project can significantly improve our knowledge on the structure and geodynamics of the transition zone between the Eastern Alps and the Pannonian basin. 
Acknowledgements The reported investigations were supported by the National Research, Development and Innovation Fund (No. K124241). The purchase of 11 new station equipment dedicated to the Hungarian AlpArray project was funded by the Hungarian Academy of Sciences (Grants EU-04/2014, EU-07/2015). AlpArray Switzerland is funded by the Swiss-AlpArray SINERGIA Project CRSII2_154434/1 by the Swiss National Science Foundation (SNSF). The authors are indebted to Jaroslava Plomerová (Institute of Geophysics, Czech Academy of Sciences) for providing a gyrocompass for the sensor orientation measurements. The map of the station locations was made by the Generic Mapping Tool software package (Wessel et al. 2013), while the noise spectra figures were generated using Matplotlib (Hunter 2007).

Open Access This article is distributed under the terms of the Creative Commons Attribution 4.0 International License (http://creativecommons.org/licenses/by/4.0/), which permits unrestricted use, distribution, and reproduction in any medium, provided you give appropriate credit to the original author(s) and the source, provide a link to the Creative Commons license, and indicate if changes were made.

\section{References}

AlpArray Seismic Network (2015) AlpArray Seismic Network (AASN) temporary component, AlpArray Working Group, Other/Seismic Network. https://doi.org/10.12686/alparray/z3_2015

Balázs A, Matenco L, Magyar I, Horváth F, Cloetingh SAPL (2016) The link between tectonics and sedimentation in back-arc basins: new genetic constraints from the analysis of the Pannonian basin. Tectonics 35(6): 1526-1559

Beyreuther M, Barsch R, Krischer L, Megies T, Behr Y, Wassermann J (2010) ObsPy: a python toolbox for seismology. Seismol Res Lett 81(3):530-533

Brisbourne A, Clinton J, Hetényi G, Pesaresi D, Aubert C, Bokelmann G, Csicsay K, Gráczer Z, Haberland C, Hawthorn D, Herak M, Kristeková M, Lane V, Lenhardt W, Margheriti L, Paul A, Péquegnat C, Plomerová J, Ritter J, Sleeman R, Vecsey L, Vergne J, Villaseñor A, Wassermann J, Wilde-Piórko M, Živčić M (2013) Technical strategy for the mobile seismological components of AlpArray. http://www. alparray.ethz.ch/organisation/documents/

Bus Z, Grenerczy G, Tóth L, Mónus P (2009) Active crustal deformation in two seismogenic zones of the Pannonian region-GPS versus seismological observations. Tectonophysics 474(1):343-352

Csontos L, Vörös A (2004) Mesozoic plate tectonic reconstruction of the Carpathian region. Palaeogeogr Palaeoclimatol Palaeoecol 210(1):1-56

Embey-Isztin A, Downes H, James D, Upton B, Dobosi G, Ingram G, Harmon R, Scharbert H (1993) The petrogenesis of Pliocene alkaline volcanic rocks from the Pannonian basin, Eastern Central Europe. J Petrol 34(2):317-343

Fodor L, Csontos L, Bada G, Györfi I, Benkovics L (1999) Tertiary tectonic evolution of the Pannonian Basin system and neighbouring orogens: a new synthesis of palaeostress data. Geol Soc Lond Spec Publ 156(1):295-334

Fuchs F, Kolínskỳ P, Gröschl G, Apoloner M, Qorbani E, Schneider F, Bokelmann G (2015) Site selection for a countrywide temporary network in Austria: noise analysis and preliminary performance. Adv Geosci 41(41):25-25

Govoni A, Bonatto L, Capello M, Cavaliere A, Chiarabba C, D'Alema E, Danesi S, Lovati S, Margheriti L, Massa M, Mazza S, Mazzarini F, Monna S, Moretti M, Nardi A, Piccinini D, Piromallo C, Pondrelli S, Salimbeni S, Serpelloni E, Solarino S, Vallocchia M, Santulin M, the AlpArray Working Group (2017) AlpArray-Italy: site description and noise characterization. Adv Geosci 43:39-52. https://doi.org/10. 5194/adgeo-43-39-2017

Gyalog L (2013) Magyarország földtani térképe, 1:500 000. Magyar Földtani és Geofizikai Intézet

Haas J, Budai T, Csontos L, Fodor L, Konrád G (2010) Pre-Cenozoic geological map of Hungary, 1: 500 000. Geological and Geophysical Institute of Hungary, Budapest

Harangi S, Downes H, Thirlwall M, Gméling K (2007) Geochemistry, petrogenesis and geodynamic relationships of Miocene calc-alkaline volcanic rocks in the Western Carpathian arc, Eastern Central Europe. J Petrol 48(12):2261-2287

Harangi S, Jankovics MÉ, Sági T, Kiss B, Lukács R, Soós I (2015) Origin and geodynamic relationships of the Late Miocene to Quaternary alkaline basalt volcanism in the Pannonian basin, Eastern-Central Europe. Int J Earth Sci 104(8):2007-2032

Hetényi G, Bus Z (2007) Shear wave velocity and crustal thickness in the Pannonian basin from receiver function inversions at four permanent stations in Hungary. J Seismolog 11(4):405-414. https://doi.org/ $10.1007 / \mathrm{s} 10950-007-9060-4$ 
Hetényi G, Stuart GW, Houseman GA, Horváth F, Hegedüs E, Brückl E (2009) Anomalously deep mantle transition zone below Central Europe: evidence of lithospheric instability. Geophys Res Lett 36(21):L21,307

Hetényi G, Ren Y, Dando B, Stuart GW, Hegedüs E, Kovács AC, Houseman GA (2015) Crustal structure of the Pannonian basin: the $\mathrm{AlCaPa}$ and Tisza terrains and the mid-Hungarian Zone. Tectonophysics 646:106-116. https://doi.org/10.1016/j.tecto.2015.02.00

Hetényi G, Molinari I, Clinton J, Bokelmann G, Bondár I, Crawford WC, Dessa JX, Doubre C, Friederich W, Fuchs F, Giardini D, Gráczer Z, Handy MR, Herak M, Jia Y, Kissling E, Kopp H, Korn M, Margheriti L, Meier T, Mucciarelli M, Paul A, Pesaresi D, Piromallo C, Plenefisch T, Plomerová J, Ritter J, Rümpker G, Šipka V, Spallarossa D, Thomas C, Tilmann F, Wassermann J, Weber M, Wéber Z, Wesztergom V, Živčić M, Team ASN, Crew AOC, Group AW (2018) The AlpArray Seismic Network-a large-scale European experiment to image the Alpine orogeny. submitted to Surveys in Geophysics

Horváth F, Bada G, Szafián P, Tari G, Ádám A, Cloetingh SAPL (2006) Formation and deformation of the Pannonian basin: constraints from observational data. Geol Soc Lond Mem 32(1):191-206

Horváth F, Musitz B, Balázs A, Végh A, Uhrin A, Nádor A, Koroknai B, Pap N, Tóth T, Wórum G (2015) Evolution of the Pannonian basin and its geothermal resources. Geothermics 53:328-352

Huismans RS, Podladchikov YY, Cloetingh SAPL (2001) Dynamic modeling of the transition from passive to active rifting, application to the Pannonian basin. Tectonics 20(6):1021-1039

Hunter JD (2007) Matplotlib: a 2D graphics environment. Comput Sci Eng 9(3):90-95

Kázmér M, Kovács S (1985) Permian-Paleogene paleogeography along the eastern part of the InsubricPeriadriatic lineament system: evidence for continental escape of the Bakony-Drauzug unit. Acta Geol Hung 28(1-2):71-84

Kovács I, Szabó C (2008) Middle Miocene volcanism in the vicinity of the Middle Hungarian zone: evidence for an inherited enriched mantle source. J Geodyn 45(1):1-17

Kovács I, Csontos L, Szabó C, Bali E, Falus G, Benedek K, Zajacz Z (2007) Paleogene-early Miocene igneous rocks and geodynamics of the Alpine-Carpathian-Pannonian-Dinaric region: an integrated approach. Geol Soc Am Spec Pap 418:93-112

Kovács I, Falus G, Stuart G, Hidas K, Szabó C, Flower M, Hegedűs E, Posgay K, Zilahi-Sebess L (2012) Seismic anisotropy and deformation patterns in upper mantle xenoliths from the central CarpathianPannonian region: asthenospheric flow as a driving force for Cenozoic extension and extrusion? Tectonophysics 514:168-179. https://doi.org/10.1016/j.tecto.2011.10.022

Krischer L, Megies T, Barsch R, Beyreuther M, Lecocq T, Caudron C, Wassermann J (2015) ObsPy: a bridge for seismology into the scientific Python ecosystem. Comput Sci Discov 8(1):014,003

McNamara DE, Buland RP (2004) Ambient noise levels in the continental United States. Bull Seismol Soc Am 94(4):1517-1527. https://doi.org/10.1785/012003001

Molinari I, Clinton J, Kissling E, Hetényi G, Giardini D, Stipčević J, Dasović I, Herak M, Šipka V, Wéber Z, Gráczer Z, Solarino S, the Swiss-AlpArray Field Team, the AlpArray Working Group (2016) SwissAlpArray temporary broadband seismic stations deployment and noise characterization. Adv Geosci 43:15-29. https://doi.org/10.5194/adgeo-43-15-2016

Peterson J (1993) Observations and modeling of seismic background noise. Technical report US Department of Interior Geological Survey, Alburquerque, New Mexico

Qorbani E, Bianchi I, Bokelmann G (2015) Slab detachment under the Eastern Alps seen by seismic anisotropy. Earth Planet Sci Lett 409:96-108

Qorbani E, Bokelmann G, Kovács I, Horváth F, Falus G (2016) Deformation in the asthenospheric mantle beneath the Carpathian-Pannonian region. J Geophys Res Solid Earth 121(9):6644-6657

Ren Y, Stuart GW, Houseman GA, Dando B, Ionescu C, Hegedűs E, Radovanović S, Shen Y (2012) Upper mantle structures beneath the Carpathian-Pannonian region: implications for the geodynamics of continental collision. Earth Planet Sci Lett 349:139-152. https://doi.org/10.1016/j.eps1.2012.06.037

Schmid SM, Bernoulli D, Fügenschuh B, Matenco L, Schefer S, Schuster R, Tischler M, Ustaszewski K (2008) The Alpine-Carpathian-Dinaridic orogenic system: correlation and evolution of tectonic units. Swiss J Geosci 101(1):139-183

Silver PG (1996) Seismic anisotropy beneath the continents: probing the depths of geology. Annu Rev Earth Planet Sci 24(1):385-432

Szabó C, Harangi S, Csontos L (1992) Review of Neogene and Quaternary volcanism of the CarpathianPannonian region. Tectonophysics 208(1-3):243-256

Tari G, Dövényi P, Dunkl I, Horváth F, Lenkey L, Stefanescu M, Szafián P, Tóth T (1999) Lithospheric structure of the Pannonian basin derived from seismic, gravity and geothermal data. Geol Soc Lond Spec Publ 156(1):215-250. https://doi.org/10.1144/GSL.SP.1999.156.01.12 
Varga P (2016) A Földrengési Observatóriumtól a Kövesligethy Radó Szeizmológiai Obszervatóriumig. Magyar Tudomány 177(10):1192-1217

Vauchez A, Tommasi A, Mainprice D (2012) Faults (shear zones) in the Earth's mantle. Tectonophysics 558:1-27

Vecsey L, Plomerová J, Jedlička P, Munzarová H, Babuška V, the AlpArray Working Group (2017) Data quality control and tools in passive seismic experiments exemplified on the Czech broadband seismic pool MOBNET in the AlpArray collaborative project. Geosci Instrum Methods Data Syst 6(2):505-521. https://doi.org/10.5194/gi-6-505-2017

Wéber Z (2016a) Probabilistic waveform inversion for 22 earthquake moment tensors in Hungary: new constraints on the tectonic stress pattern inside the Pannonian basin. Geophys J Int 204(1):236-249

Wéber Z (2016b) Source parameters for the 2013-2015 earthquake sequence in Nógrád county, Hungary. J Seismolog 20(3):987-999

Wéber Z, Süle B (2014) Source properties of the 29 January 2011 ML 4.5 Oroszlány (Hungary) Mainshock and its aftershocks. Bull Seismol Soc Am 104:113-127

Wessel P, Smith WH, Scharroo R, Luis J, Wobbe F (2013) Generic mapping tools: improved version released. EOS Trans Am Geophys Union 94(45):409-410. https://doi.org/10.1002/2013EO450001 